with a minimum of duplication of effort, can be effected only by some system of consultation and co-operative planning within larger administrative areas than are in existence at present. It was insisted, however, that in arranging such regional co-ordination, teachers should be brought into consultation. Another resolution urged that apprenticeship conditions (or their equivalent) should bo restated for the rarious industries and that the whole question of conditions of entry into industry and of the provision of opportunity for young entrants to qualify for skilled operative and higher posts should be immediately considered.

\section{Food of Icelandic Herrings*}

$\mathrm{D}^{\mathrm{n}}$ P. JESPERSEN has made an important contribution to the biology of the herring in his investigations on its food in Icelandic waters. A large number of adult fishes have been examined, mostly collected during the great herring fishery of Tceland from June until September. The nets used were the purse-seine, fishing chiefly in the surface layers near the coast, and the drift-net, fishing in the deeper water of the open sea.

The food was found to be very different in the herrings from the two nets even if they were caught in the same water, those from the seine net having far more foor in them-not one being found without food-while those from the drift-net were often empty, especially in autumn. This is presumably explained by the fact that the surface waters fished by the purse-seine nets have far more food in them in the summer than the deeper waters fished by the drift nets. The stomachs with the most food correspond with the largest catches of herrings, when there is the greatest amount of plankton. The herrings only come to these northern waters to feed at this time of year as they spawn in the warmer waters of the south and west.

The stomachs were taken from the freshly caught fishes, those from each catch $(10-20)$ being placed in a separate bag and preserved in formalin. Later, the volume of each stomach contents was noted and the food roughly analysed both quantitatively and qualitatively. The percentage of herrings from each net feeding on certain food was then estimated.

As was to be expected, copepods form the largest part of the herring food. Nearly all the purse-seine fishes were feeding on thern, euphausiids coming next in importance, amphipods, crab larvæ and pteropods also being eaten. 'The $\mathrm{dr} \cdot \mathrm{ft}$-net fishes fed largely on copepods at times and they also ate the other food mentioned above. Besides these there were present in smaller quantities in the fishes from both nets decapod and cirripede larvæ, cladocerans, gastropods, polychætes, chætognaths, fishes and fish eggs. Sometimes crab larvæ (almost entirely Hyas coarctatus, both zoeæ and megalopæ, which occurred in swarms at certain seasons) and Ammodytes were eaten in numbers.

Of the copepods, Calanus finmarchicus is much the most important food. It is found in huge masses in the waters north of Iceland, colouring the sea red, and it constitutes at least 95 per cent of the copepods eaten. Others taken by the herrings are Temora longicornis (very occasionally predominating), Calanus

" P. Jespersen, "On the Food of the Herring in Icelandic Waters" Meddelelser fra Kommissionen for Danmarks Fiskeri og Havunderse. gelser. Serie Plankton. Bind II. No. 3. 1932. hyperboreus, Metridia longa, Pseudocalanus elongatus, Microcalanus pygmoeus, Acartia longiremis and Oithona similis. Euphausiids (Meganyctiphanes norvegica, Thysannessa ( = Rhoda) inermis, Thysanoessa (= Rhoda) raschii and Thysanoessa Longicaudata) are eaten by the fishes from both nets, the adults chiefly by the drift-net herrings, the younger stages, which inhabit the surface layers, by the seine-net herrings. The pteropods Limacina retroversa and Limacina helicina occur sometimes very commonly in these seas and occasionally fill the stomachs of the driftnet herrings, especially in August and September.

\section{University and Educational Intelligence}

CAmbridge.-The Botany School has received from the estate of Mr. S. H. Bickham a valuable collection of several thousand specimens of plants and eighty-five botanical books. The bequest is a very important addition to the herbarium, since nearly all the specimens are of British plants and tho herbarium has specialised in British and colonial species.

Prof. D. B. Copland, of the University of Melbourne, has been appointed Alfred Marshall lecturer for 1933-34.

A University lecturer and a University demonstrator in the Department of Anatomy will be appointed shortly; applications should be made to Prof. J. T. Wilson, Anatomy School, Cambridge, by July 10

The electors to the Wyse studentship in social anthropology announce that they have awarded studentship of $£ 250$ for one year to Miss M. M. Hunter, Port Elizabeth Collegiate School and Girton College.

LONDON.-The following City companies have made grants to the University, payment in each case being spread over a period of years :-The Merchant Taylors' Company, $£ 5,000$; the Stationers' Company, $£ 100$. These benefactions will be applied towards meeting the cost of the new ceremonial hall to be erected on the University's site in Bloomsbury. A grant of $£ 100$ has also been made by the Guardian Assurance Company towards the cost of the new buildings.

OXForD.-The Committee of Management of the Lewis Evans Collection of Scientific Instruments has published its annual report. Many accessions are enumerated, including gifts to the library and to the collection of portraits. The need is pointed out of an endowment for a curator.

SHEFFIELD. - The following appointments have recently been made:-Dr. L. C. D. Hermitte, demonstrator in pathology, the post to be held in conjunction with that of assistant pathologist to the Royal Infirmary; Dr. Eric James, junior assistant bacteriologist and demonstrator.

Prof. E. Mellanby has resigned from the chair of pharmacology, and Mr. J. W. Kershaw from the senior lectureship in mechanical engineering.

The Association of Technical Institutions will hold its summer meeting at the Municipal College of Science, Manchester, on June 29-July 1, under the 
presidency of Sir Hugo Hirst, chairman of the General Electric Co., Ltd. The following papers will be read and discussed at the meeting : "The Training of the Technical Teacher" by J. H. Currie; "The Textile Industry" by Prof. W. E. Morton; and "Management Education, the Case System", by Principal G. A. Robinson. Further information can be obtained from Dr. H. Schofield, Loughborough College, Loughborough.

A Busk studentship in aeronautics, established in memory of Mr. E. T. Busk, will be awarded during July. The studentship is valued at $£ 150$ for one year, but may be extended to two years. The student will be expected to carry out research in aeronautics, especially in stability problems, meteorological questions bearing on flight, or the investigation of gusts. The investigations may be carried out either at home or abroad. Further information can be obtained from Prof. B. Melvill Jones, Engineering Laboratory, Cambridge.

A RECENT (November, 1932) number of "University of Colorado Studies" is devoted to the publication of a collection of abstracts of theses for higher degrees, an enterprise which few university administrations consider to be worth its expense. Here we have a hundred and seventy abstracts, on an average 350 words each, constituting a cross-section of the course of advanced study and research in progress in the University. More than one-fifth of the theses are records of research in pedagogy. Of the remainder, half deal with humanistic and half with scientific topics. Theses on engineering subjects number 17 (electrical engineering 13), biological 14, chemical 10 , physical and geological 6 each. A fairly large number of them are records of regional surveys.

The Universities Review has in its April issue several articles of unusual interest. Prof. $\mathrm{S}$. Brodetsky describes the plight of Jewish university teachers in Germany and the prominent place taken by Jews in intellectual life in that country. $\mathrm{He}$ explains the growth of the pscudo-scientific antiSemitism which found such a successful exponent in Houston Stewart Chamberlain, whose work "The Foundations of the Nineteenth Century" formulated German racial pride and its application to Jews in a way that won the approval of the Kaiser and his advisers and added venom to an already virulent complex, aggravated and sharpened since the War by the rapid growth of an academic proletariat in excess of the capacity of the country to absorb them in useful occupations. The work of its Internitional Relations Committee forms the subject of the presidential address to the Association of University Teachers which is reproduced in this number, and there is a report on continental students in British universities. Acadcmic freedom in the United States is discussed by Preston Slosson who corrects the distorted picture drawn by Upton Sinclair in his "Goose Step" by showing that plutocracy is only one of a host of dangers by which freedom is beset. An informative article by $F$. A. Went and $R$. C. McLean on the Dutch university system is a useful addition to the series of similar papers which the Review is publishing Eugen Rosenstock writes about the "mortal disease" of specialisation and urges by way of remerly the grouping of opposites into a sort of common life as in settlements, summer schools and camps.

\section{Calendar of Nature Topics}

\section{Shamal}

The prevailing wind in the Persian Gulf and the Sea of Oman blows from the north-west and is called by the Arabs 'shamal'. A shamal may occur in any month of the year, but it blows almost without cessation during June and the early part of July, when it is known as the 'great' or 'forty-day shamal'. A shamal may set in suddenly at any hour of the day or night, and generally lasts from one to five days. Although the wind is not usually strong, rarely exceeding thirty miles an hour, it is very hot and dry, and carries great quantities of dust from the deserts of Persia and Mesopotamia. The sky is cloudless, but the haze is often so thick as to obscure the land, making navigation dangerous, and the decks of ships far out at sea are covered by a fine impalpable dust.

\section{Frequency of Birds}

The number of birds in an area fluctuates considerably throughout the year, under the influence of changing quantities of food, whether vegetable or animal, of birth rate and death rate, and of migration. But in inland parts of the northern hemisphere the numbers reach their climax in June, a fact to be correlated with the height of the nesting season in the latter half of May (sce "Nature Calendar", March 25, p. 445). In June the newly-fledged broods of the year still keep together in their home area, but as the year progresses; their ranks are thinned by death and the relicts scatter over a wider territory.

An interesting confirmation of the June climax in bird numbers comes from Yosemite Valley in the Yosemite National Park, California. There, since the summer of 1920, Mr. and Mrs. Charles W. Michael have kept daily records of all species of birds seen by them. At the end of each month a summarised report of all observations for the preceding thirty days has been sent to the Museurn of Vertebrate Zoology, Berkeley, California ; and now Dr. Jean M. Linsdale has used the daily records for the period August 1, 1920-November 30, 1931, to estimate the relative frequency of occurrence of the birds in the Valley (Condor, 34, 221; 1932.) The species seen numbered 151 , but of these only 40 were observed on more than 20 per cent of the days. A rough test of the relative numbers of birds present will be given by comparing the monthly numbers of species seen every day during the month. Extracting from Dr. Linsdale's statistics, we find that these numbers form a simple unimodal eurve, at its lowest in January and December with 1 and 0 species seen every day, and rising to an apex in mid-summer with 13, 20, 12 in May, June and July respectively. This indication that June is the month of highest bird population in Yosemite Valley is confirmed by analysis of the monthly totals of observations of the forty most common birds.

\section{Breeding Season of Sea-Lions in California}

From the middle of June to the middle of July the breeding season of the sea-lions of California is at its height. Then the breeding adults, grouped in harems of females dominated by a master bull, form rookeries upon the islands off the coast, and when the single pups are born the sea-lion population is at its maximum. It was at this period that, in 